\title{
[rec.] Irena Bogoczova, Language Policy in the Czech Republic in the Context of the Situation in Slavic-Speaking Territories, Uniwersytet Ostrawski, Ostrava 2021
}

Przede mną nowa książka Ireny Bogoczovej Language policy in the Czech Republic in the context of the situation in Slavic-speaking territories (Polityka językowa w Republice Czeskiej w kontekście ogólnej sytuacji na Słowiańszczyźnie, 2021), wydana w Ostrawie przez tamtejszy uniwersytet. Warto powiadomić czytelników o jej istnieniu choćby w zwykłej sprawozdawczej recenzji, jak niniejsza. Rezygnując z umieszczenia książki na tle szerszego dorobku językoznawczego polskiego słowianoznawstwa, dołączę w zamian przy końcu uwagi o możliwościach wykorzystania jej w dydaktyce języka polskiego. Zdaje się, że to będzie pierwsza recenzja polska, o ile nie pierwsza w ogóle. Autorka jest dobrze w Polsce znana z udziału w konferencjach, współpracy z polskimi uniwersytetami, autorami i oczywiście własnych prac ogłaszanych po czesku i polsku (kilka z nich przywołała, poszerzając je o nowe dane - s. 5-6). Książka składa się ze wstępu, 11 rozdziałów, streszczenia w trzech językach: angielskim, czeskim, polskim, literatury przedmiotu, indeksu nazw, licząc 88 stron. Jej celem jest podstawowy opis tego, jak dzisiejsze standardowe języki słowiańskie, szczególnie czeski, funkcjonują w publicznej komunikacji, jak wyglądają relacje między kulturalną i potoczną czeszczyzną, czy nawet spór między nimi, a także rola normy, polityka językowa i polityczność lingwistyki (czy istnieje apolityczna lingwistyka?). Omówione zostały odmiany terytorialne i socjalne języka czeskiego na tle polityki językowej ujętej z kolei w kontekście warunków panujących w słowiańskich państwach postkomunistycznych.

Wstęp zawiera deklaracje przedmiotowe i metodologiczne: języka nie sprowadza się tu tylko do porozumiewania, lecz wskazuje na kilka innych, nie mniej ważnych, jego funkcji, jak narodowa, ideologiczna, polityczna, kulturalna, cywilizacyjna. Zwraca się też uwagę na rolę języka w uświadamianiu sobie przez jednostki ich unikatowości i odrębności w społeczeństwie, jak też, z jednej strony, scalanie grup, począwszy od domowej, a z drugiej — oddzielanie ich od siebie. Również wiedzy o języku nie ogranicza się do językoznawstwa, lecz podkreśla jej znaczenie dla nauczania, stosunków społecznych, polityki, ideologii.

Dla opisu tych zagadnień za punkt wyjścia wzięto trzy obiekty: język — naród państwo (rozdz. 1), które są podstawowymi filarami społeczeństw słowiańskich co najmniej od czasów romantycznych. Właśnie romantyczni nacjonaliści, podpierający się koncepcją narodu Johanna G. Herdera i później Ernesta Renana, wzmacniali u Słowian żywe przekonanie, że jeden naród = jedno państwo = jeden język, niekiedy dodawano do 
tego zestawu religię (tego rodzaju całość odpowiada sytuacji w jednonarodowej Polsce). W ten sposób i narody, i języki słowiańskie mocno się oddzieliły, zróżnicowały, choć co pewien czas słyszy się o scalającej Słowiańszczyznę idei języka i narodu hegemonicznego, upatrywanego w Rosji i języku rosyjskim. Idea ta nie została zrealizowana z powodu imperialnych dążeń Rosji i wspomnianego przekonania, że język rozumiano jako pierwszy i najważniejszy znak narodowej identyfikacji, przed lub ponad terytorium, pochodzeniem, historią, tradycją, religią. Tych czynników jednak nie da się pominąć, są zbyt ważne dla narodu i języka. Do tego dochodzą czynniki geograficzne, jak choćby górzyste lub nizinne ukształtowanie terenu. W tym pierwszym, silniej zatem podzielonym przez czynniki naturalne, powstaje więcej dialektów czy gwar, czego przykładem mała Słowenia z sześcioma lub siedmioma dialektami, niż na terenie płaskim, otwartym, z jednym ośrodkiem władzy.

Czynniki terytorialne, geograficzne, klimatyczne wraz ze statusem języków wpływają na ich liczbę (rozdz. 2). Zwykle przyjmuje się, że jest 12 języków słowiańskich, ale też wymienia się 18, 30, 40 w zależności od kryteriów wyróżniania i włączania także języków martwych i regionalnych. Rozbieżności, jak widać, są znaczne. Wyzwalanie się narodów słowiańskich z objęć mocarstw, w tym emancypacja językowa, prowadzi do zwiększenia liczby języków słowiańskich, czemu sprzyja na przykład nacisk na prawa człowieka. Nieoczywiste jest również, co uznać za język, co za dialekt, a co za mniejszość narodową. Autorka odnotowuje, że w Polsce za mniejszości narodowe uważa się te, które należą do narodów mających swoje państwa, a za etniczne - inne grupy, jak Łemkowie, Karaimi, Tatarzy, Romowie. Kaszubi są grupą regionalną, a kaszubski uznaje się za język, choć w przeszłości — dodam — polscy lingwiści skłonni byli uważać go za dialekt polszczyzny. Niejasna pozostaje sprawa narodowości śląskiej i języka śląskiego, najczęściej określanego jako regionalny, ale z ambicjami do stania się językiem etnicznym; zarazem uznaje się go za dialekt polszczyzny. Wiele zależy od statusu języka, cechy stopniowalnej: język mniejszości narodowej, język mniejszości etnicznej, język grupy regionalnej. Język się wzmacnia, gdy jest prawnie chroniony, czego domagają się zwłaszcza jego obrońcy i miłośnicy, w tym puryści. Największą rolę odgrywa państwowa polityka językowa (o tej w rozdz. 4), gdyż sprzyja wyłanianiu się i umacnianiu standardowej odmiany języka, ustalaniu i opisywaniu reguł, doskonaleniu tej odmiany, w czym niebagatelną rolę odgrywa szkolnictwo.

W językach słowiańskich odmianę standardową w poszczególnych krajach określa się dość podobnie jako książkową, literacką, kulturalną, pisaną, a przeznacza do używania w sytuacjach oficjalnych (s. 23). Istnienie, rozwój i ochronę tej odmiany wspierają konstytucje lub ustawy o ochronie języka, jak na przykład w Polsce. Stosunki między odmianą standardową a innymi substandardowymi układają się różnie, co poparto dwoma przykładami: w Słowenii języki węgierski i włoski są współoficjalne ze słoweńskim, w Czarnogórze język czarnogórski jest oficjalny, ale też w tej roli używane są serbski, bośniacki, albański, chorwacki (s. 25).

Sytuacja językowa w Czechach (o tym rozdz. 5) jest prosta: jeden naród i jeden język. Wprawdzie obok Czechów oficjalny status autochtoniczny mają jeszcze Słowacy, Polacy, Niemcy, ale razem stanowią tylko 2\% ogółu ludności. Podział terytorialny obejmuje cztery dialekty: czeski, centralny morawski, wschodni morawski, śląski. Podział socjalny i zarazem poniekąd stylistyczny obejmuje takie odmiany, jak spisovná čeština (czeski język ogólny kulturalny, literacki język czeski; standard Czech), hovorová čeština (mówiona forma języka kulturalnego; colloquial Czech), obecná čeština (czeski nieliteracki; Common Czech) oraz běžně mluvený český jazyk (nieliteracki język czeski mówiony). 
Standardowy czeski (spisowná čeština) określony został w książce jako wielofunkcjonalny, bo obsługuje szkoły, dziennikarstwo, literaturę, a także codzienne mówienie; istnieje jako mówiony i pisany; służy do wyrażania narodowej tożsamości Czechów. Z kolei mówiony nieliteracki używany w zachodniej części państwa czeskiego, w tym w Pradze, ma charakter interdialektalny. I jeszcze zwyczajny, codzienny mówiony czeski (běžně mluvená čeština) będący mieszaniną zachodniego czeskiego i wschodniego z terenów Moraw i Śląska. Wszystkie odmiany łączą się pod nazwą narodowy język czeski (český národní jazyk) (szczegóły dotyczące odmian i ich nazw na s. 28-32).

Czeską politykę językową (zob. rozdz. 6) przedstawia się jako typową politykę rozmytą, nieostrą, zarazem liberalną, łagodną, wolną od nieracjonalnych dążeń do czystości i nadmiernego poczucia narodowej wyjątkowości. Te cechy spowodowały, że obyło się bez wojen o język, poza jedną o lącznik (hyphen war) z lat 1990-1992, czyli o to, jak pisać nazwę kraju składającego się z Czech i Słowacji: z łącznikiem czy bez niego. Konstytucja Czechosłowacji z 1948 roku wymieniała dwa główne języki: czeski i słowacki. W następnej z 1992 roku wymienia się: vyučovací jazyk (language of instruction), úřední jazyk (official language), jednací jazyk (procedural language), smluvni jazyk (contractual language) i služební jazyk (language of [military] service). Nie ma dzisiaj w Czechach pojęcia języka państwowego.

W rozdz. $7 \mathrm{w}$ dziesięciu tezach przedstawiono sytuację językową w Czechach: 1) nie jest ona wyjątkowa, jak się sądzi, i nie bardziej skomplikowana niż w innych krajach; 2) wspótistnieją dwa standardy językowe, jeden jeszcze z końca XVI wieku, drugi z końca XVIII i początku XIX stulecia; 3) między standardowym czeskim a zwykłym użyciem języka panuje napięcie; 4) ten pierwszy nie jest od początku matczynym językiem członków narodu czeskiego; mówienie nim wymaga pewnego stopnia intelektualnego wysiłku, w tym chodzenia do szkoły, demokratycznej i demokratycznie traktującej odmiany, więc nie prowadzi do utraty naturalnej kompetencji językowej dzieci; 5) użytkownicy czeskiego są w stanie przełączać się z kodu na kod dość łatwo, co nie stanowi przejawu schizofrenii językowej, jak się zarzuca; 6) sytuację przełączania się i zastanawiania, jak coś powiedzieć poprawnie, czyli zgodnie ze standardową odmianą (tu: czeskim), widać w wielu krajach; 7) standardowa odmiana jest uniwersalna, zdolna do pełnienia wielu funkcji. Autorka nie popiera dążeń do nadania czeskiemu mówionemu nieliterackiemu (Common Czech) statusu, jaki ma mówiona forma języka kulturalnego (hovorová čeština, colloquial $\mathrm{Czech}$ ), bo nie spełnia dwóch warunków: nie występuje na całym terytorium społeczności mówiącej, nie spełnia ogólnokrajowych funkcji komunikacyjnych, głównie stylistycznych, wprowadza też zamieszanie co do poprawności (8). Nie popiera również dążeń do utożsamiania czeskiego języka ogólnego, literackiego (spisovná čeština, standard Czech) z czeskim nieliterackim (obecná čeština, Common Czech), nawet gdy ten z dawien dawna przeważa, gdy obsługuje większość mówiących; lecz nie wszystkich (9). Nie popiera także przekonania, że standardowy czeski szkodzi tym czy innym formom czeskiego nieliterackiego (10). Ogólnie rzecz biorąc, unika podziału na dwa obozy, to jest - zwolenników standardowego czeskiego i nieliterackiego czeskiego. O przewadze tego pierwszego świadczy, że zajmuje on wiele kluczowych miejsc, obsługuje wiele ważnych sytuacji: w nauce, szkole, polityce, administracji, armii, prawie, literaturze, a odmiana niestandardowa spełnia się w prywatnych rozmowach oraz w handlu, usługach, opiece zdrowotnej, rozrywce. 
Spór toczy się również o normę językową i postawy wobec niej (rozdz. 8). Zdaniem autorki każda odmiana posiada normę, nie tylko standardowa. Różne grupy mają normy odmiennie wartościowane, na przykład Morawianie i Ślązacy skłonni są widzieć własny dialekt jako mniej ważny, więc na co dzień mówią standardowym czeskim uważanym za lepszy.

Norma, jak wiadomo, jest zróżnicowana, na przykład inna dla pisanego i mówionego: dla pierwszego raczej wysoka, modelowa, dla drugiego użytkowa, zwyczajowa, nawet niska. Norma odmiany standardowej przeważa, bo ma zasięg ogólnokrajowy, chroni ją prawo, popierają i doskonalą pisarze, tłumacze, prawnicy i szczególnie językoznawcy, więc grupy wpływowe. Pod ich wpływem zwykli użytkownicy mogą zwątpić we własne kompetencje nabyte wraz z językiem matczynym i przejąć nowe wartości niesione przez „nowy” język. Nabywanie go bywa konfliktowe, niekiedy odbierane jako atak, zwykle jednak chodzi o ochronę przed takimi zjawiskami na obszarze słowiańskojęzykowym, jak nadmiar anglicyzmów, utrata językowej wolności, niepożądana wielojęzyczność przejawiająca się wzmocnieniem pozycji języków mniejszości, heteroglosja oznaczająca wzmocnienie pozycji dialektów, zwykłego mówionego.

Norma języka standardowego bywa przez mówiących chciana i przyjmowana, jak też przeciwnie - niechciana i odrzucana (o tym w rozdz. 9). Obrońcy nieliterackiego mówionego czeskiego sądzą, że znajduje się on w wyjątkowej sytuacji: między standardem i terytorialnie ograniczonymi dialektami, a zarazem mówi nim większość Czechów. Standardowego czeskiego wyuczyli się w szkole, jako języka obcego, i na tym dla wielu mówiących skończyła się jego przydatność — wnioskują bowiem, że nie jest konieczny. Chcą zachować niezależność od autorytetów, władzy, boją się utraty naturalnej pewności językowej, sądzą, że autorytety, w tym lingwiści, nie mają prawa narzucać standardowego czeskiego, a standardowość nie może być głównym kryterium oceny, bo każda odmiana języka jest do przyjęcia, o ile cechuje ją funkcjonalność (s. 57). Morawianie i Ślązacy świetnie porozumiewają się na co dzień za pomocą własnych dialektów, więc argumenty za standardowym czeskim ich nie przekonują.

Związki między odmianą standardową a pisaną i mówioną (rozdz. 10) dotyczą tego, która $z$ nich jest bliżej normy standardowej i czy jej przestrzeganie wymaga większego umysłowego wysiłku, a nieprzestrzeganie spotka się z negatywną oceną odbiorców, zwłaszcza za błędy w odmianie pisanej. Autorka przypomina typową charakterystykę pisanego (tekstu), która prowadzi do stawiania go w opozycji wobec mówionego, choć językowa praktyka nie układa się dychotomicznie, skoro są przykłady wypowiedzi wyrafinowanych, dopracowanych, na poważne tematy, i przeciwnie — pisanych banalnych, prostych. Celowo nie przeprowadza dokładnej argumentacji przeciwko binarnemu ujęciu (co u nas zrobił Bakuła w pracy Mówione $\approx$ pisane, 2008), niemniej stwierdza wyraźnie, że upieranie się przy istnieniu dwóch norm, pisanej i mówionej, niezupełnie potwierdza się w rzeczywistości. Cały ten układ jest dynamiczny, w ciągłym ruchu są zwłaszcza normy odmiany mówionej.

Kontrowersje towarzyszą sprawom poprawności i czystości języka oraz jego odmian (rozdz. 11). Przekonania, że mówiący obawiają się użyć standardowego czeskiego, a zamiast niego wolą mówiony nieliteracki, odbiegają od rzeczywistości, co wynika z badań autorki z zespołem (Fenomén spisovnosti v současné české jazykové situaci, 2011). Zgłasza ona zastrzeżenia wobec hiperpoprawności i puryzmu, niekiedy utrudniającego porozumiewanie się i rozumienie (zob. s. 65-67). 
Jak widać, książka daje bardzo dobry przegląd sytuacji językowej w Czechach, obfituje w różnorodne treści, zwykle kontrowersyjnie postrzegane, ujęte dynamicznie, co zapewne pobudzi uwagę czytelników. W zestawie bibliograficznym przeważają, co zrozumiałe, opracowania czeskie, zaraz po nich polskie (zwłaszcza często cytowany W. Lubaś), są także trzy pisane po chorwacku, dwa po rosyjsku, słowacku oraz serbsku i jeden po słoweńsku.

Tyle samej recenzji, pozostaje jeszcze odpowiedź na pytanie, co może zyskać dydaktyka języka polskiego i kształcenie językowe w polskich szkołach z książki I. Bogoczovej. Uświadamia ona brak tematu polszczyzny na tle innych narodów słowiańskich, we współpracy i w konflikcie, nie ma choćby jednego odniesienia do rozpadu Jugosławii, powstania Czech i Słowacji, nacjonalizmów językowych — uczniowie wnioskują, że nic się obecnie nie dzieje z językami słowiańskimi i polskim na ich tle, $w$ ten sposób język na lekcjach polskiego znajduje się poza realnym światem, poza bieżącymi przemianami. A przecież między polskim a czeskim i śląskim cały czas istnieje napięcie. Nie ma w podręcznikach kontrowersyjnej sprawy (dialektu?, języka?) śląskiego. W ogóle nie ma spraw bieżących, trudnych i przy tym zabarwionych politycznie. Nawet gdy podejmuje się w szkole niektóre zagadnienia opisane w książce, to brakuje przedstawienia ich dynamicznie, jako czegoś żywego i dziejącego się tu i teraz. Nie stawia się wyraźnie kwestii politycznej natury języka i językoznawstwa — o ile o zaprzęgnięciu języka do polityki mówi się na przykładzie manipulacji i nowomowy, o tyle o językoznawstwie jako zamieszanym w politykę już nie; nie bierze się pod uwagę stosunku mówiących do języka, ich przekonań na ten temat, udziału w tworzeniu mowy ojczystej, rozbieżności między jednostkami i grupami - szkoła narzuca gotową wiedzę o języku, nie pokazuje, jak go badać. Przez dziesięciolecia $\mathrm{w}$ dydaktyce powtarzano za językoznawstwem niesprawdzone dokładnie mniemania o opozycji mówionego i pisanego, ale gdyby częściej zaglądano do prac czeskich lingwistów, zapewne zagadnienie to zostałoby rozsądniej ujęte.

Wydaje się, że zaciekawi uczniów wspomniana przez autorkę zależność języka od ukształtowania terenu, co przejawia się tym, że w górach dość mocno podzielonych przez czynniki naturalne powstaje więcej dialektów i gwar niż na nizinach. Nie mniej ciekawa wydaje się sprawa puryzmu i może nawet bardziej samych purystów. Owszem, podręczniki informują o puryzmie językowym, ale zbyt niemrawo, bez powiązania z palącą ideą narodowości, jak i codziennego współżycia. Przecież uczniowie mogą, obserwując lub ankietując, dowiedzieć się, czy w ich regionie działają puryści, jak się przejawia ich aktywność, czy na co dzień są do zniesienia, czy jednak grzeszą uciążliwością, czy są patriotami, czy nacjonalistami, czy już szowinistami. A może nie ma w ogóle purystów językowych w Polsce?

O słowiańskości języka polskiego mówi się na lekcjach w zasadzie tylko w związku z jego pochodzeniem, potem nieco przy romantyzmie i na tym koniec, co uznaję za przejaw samopomniejszania, zacierania własnych śladów obecności. Czy nie zaciekawi uczniów i nie pobudzi do dyskusji fakt, że — jak się wydaje — w mniejszości są Polacy, dla których pierwszym skojarzeniem tożsamościowym jest ich własna rodzima słowiańskość, określanie siebie jako Polaka Słowianina, a nawet Polaka-Słowianina? Może więc nauczyciele języka polskiego i dydaktycy zachęcą siebie i uczniów do częstszego używania wyrazów i wyrażeń, takich jak Słowianin, Słowianie, słowiańskość, języki słowiańskie, kultura słowiańska, tradycja słowiańska, wierzenia słowiańskie. Słowiańszczyzna 
żyje, lecz więcej dla szerszego uświadomienia tego faktu uczyniła muzyka folkowa i piosenka niż lekcje języka polskiego.

Co najmniej tyle pożytków dla kształcenia językowego i kulturowego widać w tej chwili z omówionej książki jako dostarczycielki wiedzy i inspiracji.

Kordian Bakuła

ORCID: 0000-0002-4049-846X

Uniwersytet Wrocławski

https://doi.org/10.19195/1642-5782.19(29).11

[rec.] Марія Зелінська, Комунікативна компетенція

молодих носїв польської мови західних областей України

[Maria Zielińska, Kompetencja komunikacyjna młodych użytkowników języka polskiego zachodnich obwodów Ukrainy], POSWIT, Drohobycz 2018

Tematyka omawianej publikacji wpisuje się w badania nad błędami obcokrajowców w języku obcym/drugim (dalej: J2). Analizy lapsologiczne mają bogatą tradycję w glottodydaktyce. Za ich początek uznaje się artykuł Stephena Pita Cordera z 1967 roku The significance of learners' errors, w którym autor podkreślił wagę zdobywania wiedzy na temat autentycznych błędów uczących się w J2. Znaczenie błędów ujawnia się w trzech aspektach: jako informacja o tym, co uczący się już przyswoił; jakie techniki i strategie uczenia się rozwinął oraz w jaki sposób przebiega akwizycja języka. Podkreśleniu glottodydaktycznej relewancji błędów językowych w J2 towarzyszy u Cordera przekonanie o naturalnym i niezbieżnym charakterze błędów, a także ważna refleksja metodologiczna: jak należy badać błędy językowe ${ }^{1}$.

Badania nad błędami stanowią najważniejsze działanie w zakresie empirycznego rozpoznawania trudności językowych użytkowników danego J1 w konkretnym J2. Najmocniej wydają się one pożądane tam, gdzie na styku J1 i J2 mocno działa transfer negatywny - jedna z najbardziej uchwytnych przyczyn błędów językowych. Interferencja międzyjęzykowa jest mechanizmem lapsogennym w przypadku spotkania J1 i J2 typologicznie podobnych i pokrewnych. $Z$ tym właśnie przypadkiem mamy do czynienia u uczących się języka polskiego jako obcego (dalej: JPjO) Ukraińców. Popełniają oni wiele interlingwalnych błędów językowych wynikających ze zbieżności pomiędzy ukraińskim a polskim. Sprawności językowe w posługiwaniu się językiem polskim u Ukraińców wykazują charakterystyczną przepaść pomiędzy wyższym poziomem umiejętności receptywnych (rozumienie ze słuchu, czytanie) a niższym produktywnych (mówienie i pisanie). Te ostatnie są trudne dla omawianej grupy uczących się właśnie ze względu na niedostateczne zróżnicowanie J1 i J2 na wielu poziomach i we wszystkich podsystemach. Cierpi na tym poprawność językowa komunikatów w języku polskim Ukraińców, a błędy, które nie zostaną przepracowane, mogą ulec fosylizacji, czyli „skamienieniu” w interjęzyku, co w konsekwencji może spowodować brak możliwości dalszego rozwoju językowe-

${ }^{1}$ J. Arabski, Errors as Indications of the Development of Interlanguage, Katowice 1979, s. 16. 